\title{
NEURORECURRENCES FOLLOWING TREATMENT WITH ARSPHENAMIN *
}

\author{
ERNEST L. ZIMMERMANN, M.D. \\ BALTIMORE
}

The factors which predispose a patient to neurosyphilis have been much discussed, but they are still obscure. In general three factors may be said to determine involvement of the central nervous system: variations in reaction of infected persons to Spirochaeta pallida, the strain of the infecting organism, and the amount and character of antisyphilitic treatment. Antisyphilitic treatment, properly employed, may prevent or suppress the development of clinical neurosyphilis; on the other hand, such treatment may, under certain conditions, favor its development or hasten its clinical onset.

The occurrence of precocious clinical neurosyphilis following one or several doses of arsphenamin soon sobered early enthusiasm in the drug. It is unnecessary to dwell on the controversy concerning the origin of these so-called neurorecurrences or neurorecidives; they are now considered syphilitic in nature.

From the opening of the Syphilis Clinic of the Johns Hopkins Hospital in 1914 to Sept. 1, 1921, 7,065 patients with syphilis have been treated. Of these 1,400 , or 20 per cent., have had cases of primary or early secondary syphilis. Among this group neurorecurrences have developed in twenty-three patients, an incidence of 1.64 per cent. It is obvious that that figure is only approximate and actually too low, as many patients with early syphilis who attend the clinic until rendered asymptomatic by a few doses of arsphenamin and are accordingly ideal subjects for the development of neurorecurrences, subsequently seek treatment elsewhere. Sixteen additional neurorecurrences have been included in this report, comprising patients who had received initial treatment elsewhere and had already developed symptoms of neurosyphilis at the time of their first visit to the clinic, and those seen in the Syphilis Clinic of the Baltimore Eye, Ear and Throat Charity Hospital.

In general, patients with early syphilis are subjected to a standard course of treatment. Briefly, this consists of alternate courses of arsphenamin and mercury, the initial course consisting of six doses of 0.3 to $0.4 \mathrm{gm}$. each of arsphenamin at weekly intervals, followed by a course of mercury by inunction, commenced one week after the last dose of arsphenamin and continued about eight weeks before arsphenamin is resumed.

\footnotetext{
*From the Syphilis Department of the Medical Clinic, Johns Hopkins Hospital.
} 
As to the number of treatments received by patients with neurorecurrences: Four received one dose; seven, two doses; two, three doses; one, four doses; four, five doses; sixteen, six doses; two, seven doses; one, ten doses, and one, twelve doses. Of the twenty-three patients who received initial treatment in this clinic, only three had received mercury. That sixteen received six doses of arsphenamin is due to the fact that the usual course consists of six injections, and treatment is often interrupted at this point when inunctions are prescribed. In every instance there was a lapse in treatment before the onset of neurologic symptoms. The usual interval between the last injection of arsphenamin and the development of a neurorecurrence was from four to eight weeks, with extremes of one week (?) and five months.

Table 1.-Cranial Nerve Involvement in Neurorecurrences

\begin{tabular}{|c|c|c|}
\hline Nerves Involved & Author's Cases & Gennerieh's Cases \\
\hline 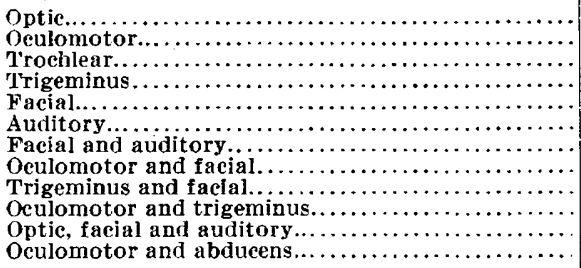 & $\begin{array}{r}3 \\
1 \\
1 \\
-3 \\
3 \\
5 \\
10 \\
1 \\
1 \\
1 \\
\cdots\end{array}$ & $\begin{array}{l}1 \\
4 \\
6 \\
2\end{array}$ \\
\hline
\end{tabular}

\section{SYMPTOMATOLOGY OF NEURORECURRENCES}

There is no typical clinical picture. Intense symptoms of meningitis, such as severe headache, nausea, vomiting, at times delirium and even coma, may predominate. On the other hand, such symptoms may be slight or even absent, and the neurorecurrence may manifest itself by one or several focal lesions. Clinically three groups may be differentiated: (1) acute syphilitic meningitis, with or without focal lesions; (2) meningitis of moderate or slight intensity, manifesting itself chiefly by headache and focal lesions, and (3) no general symptoms of meningitis, the entire complaint being due to a focal lesion.

Table 1 , indicating the cranial nerves affected, shows that the facial and auditory nerves are especially liable to be involved. Ten patients with auditory involvement were subjected to detailed otologic examination. Six showed a combined cochlear and vestibular lesion, three an isolated lesion of the cochlear division and one an isolated vestibular defect. The frequency of facial and auditory nerve involvement is also shown in Gennerich's ${ }^{1}$ series of twenty-five neurorecurrences.

1. Gennerich, W.: Die Syphilis des Zentralnervensystems, Berlin, Julius Springer, 1921, p. 60. 
The onset of auditory symptoms was in the majority of cases gradual. In one patient who complained of headache and a facial paralysis, involvement of the vestibular branch of the eighth nerve was found only on otologic examination. On the other hand, the onset may be sudden. One patient went to bed apparently normal but found himself next morning almost completely deaf. Gennerich ${ }^{2}$ ascribed such an apoplectiform onset to a thrombotic lesion.

Changes in the optic nerve may vary from a mild papillitis discovered only on ophthalmoscopic examination to an optic neuritis simulating choked disk from increased intracranial tension. According to Igersheimer, ${ }^{3}$ optic neuritis in neurorecurrences may be differentiated from the choked disk of increased intracranial pressure by the presence of vitreous opacities, a central scotoma and a decrease in dark adaptation.

\section{GENESIS OF NEURORECURRENCES}

Ehrlich's ${ }^{4}$ explanation of neurorecurrences is based on the theory of a sterilization which just falls short of being complete. Because of therapeutic interference the host has failed to develop resistance against the spirochetes which survive in isolated foci. In these foci the organisms find an environment in which they are able to set up an intense lymphoid reaction analogous to that occurring in the chancre. - If the surviving organisms happen to be situated in nerve tissues a neurorecurrence may develop. An analogous reaction is observed in connection with cutaneous rests of spirochetes, which under similar circumstances produce chancriform papules. ${ }^{5}$

Ehrlich's explanation is supported by two facts: In the first place, neurorecurrences are limited with few exceptions to patients with primary or early secondary syphilis, a period in the disease when spirochetes are especially accessible to arsphenamin. Second, the serology of neurorecurrences is in accord with such a conception. It is striking that in this series, of the thirty-two patients on whom a Wassermann test was performed a relatively short time after the appearance of nervous symptoms, the result was negative in twenty-two.

It is an accepted fact that spirochetal invasion of the neuraxis occurs in the great majority of cases during the general dissemination of the primary period. One must not assume, however, that a normal spinal fluid at the time of primary or early secondary manifestations insures against the possibility of the development of an eventual

2. Gennerich, W.: Die Syphilis des Zentralnervensystems, p. 61.

3. Igersheimer, J.: Syphilis des Auges, Berlin, Julius Springer, 1918, p. 414.

4. Ehrlich: Ueber Salvarsan, München. med. Wchnschr. 58:2481 (Nov. 21) 1911.

5. Bettmann: Ueber kutane Frührezidive der Syphilis nach Salvarsanbehandlung. Deutsch. med Wchnschr. 37:438, 1911. 
neurosyphilis. It merely signifies absence of meningeal irritation. Altman and Dreyfus ${ }^{6}$ report the case of a patient, who showed a normal spinal fluid at the time of early secondary manifestations. Failing to return after one dose of arsphenamin, he came under observation some weeks later with a combined seventh and eighth nerve lesion and with spinal fluid abnormalities. Such a clinical observation is in accord with the results of Marinesco and Minea, ${ }^{7}$ Steiner ${ }^{8}$ and Artz and Kerl, ${ }^{9}$ who succeeded in producing positive inoculations in rabbits with the apparently normal spinal fluid of patients with early secondary syphilis.

Neurorecurrences have been confused with Jarisch-Herxheimer reactions. However, the two processes are fundamentally different. A Herxheimer reaction represents an intensification of syphilitic symptoms occurring usually some hours after the administration of antisyphilitic treatment. It is usually ascribed to a temporary stimulation of spirochetes or to the action of toxins liberated from destroyed organisms. It can as well be explained on the basis of a reaction between syphilitic processes and antisyphilitics. The latter conception is probable in connection with Herxheimer reactions occurring in tertiary lesions unless one accept the explanation that the action of the relatively few organisms in such lesions is enough to produce a change in already sensitized tissues. Moreover, changes simulating Herxheimer reactions have been noted in nonsyphilitic dermatoses following the administration of arsphenamin. ${ }^{10}$ In neurosyphilis a Herxheimer reaction may manifest itself as an accentuation of symptoms already present, for instance, the intensification of syphilitic headaches. It may be the first indication that serious changes are developing in the nervous system. Facial paralysis ${ }^{11}$ and auditory disturbances have appeared some hours after an injection of arsphenamin in patients previously asymptomatic of neurosyphilis.

A neurorecurrence, on the other hand, does not indicate an actual stimulation of spirochetes or a direct action of arsphenamin on syphilitic processes. It occurs weeks or months after the interruption of antisyphilitic treatment and is the result of resumed activity of temporarily suppressed organisms in a host who has not been able to develop resistance owing to therapeutic interference. Occasionally a recurrent

6. Altman and Dreyfus: München. med. Wchnschr. 60:531 (March 11) 1913.

7. Marinesco and Minea: Acad. de Sc. Sem. Med., 1914, p. 357.

8. Steiner: Impfexperiments mit Spinalflüssigkeit von Syphilitikern, Neurol. Centralbl. 33:132, 1914.

9. Artz and Kerl: Ueber experimentelle Kaninchensyphilis und ihre praktische Bedeutung, Wien. klin. Wchnschr. 27:785, 1914.

10. Hesse, Max: Die Jarisch-Herxheimersche Reaktion, Wien klin. Wchnschr. 32:439, 1919 .

11. Dreyfus, G.: Ueber Enstehung. Verhütung und Behandlung von Neurorezidiven, München. med. Wchnschr. 59:2233 (Oct. 8) 1912. 
secondary syphilid will develop simultaneously with the appearance of a neurorecurrence. Such a cutaneous lesion could not be interpreted in the sense of a Herxheimer reaction.

The following case exemplifies the temporary suppression of a syphilitic infection by arsphenamin and the subsequent flaring up of neurosyphilis when treatment is suspended. A patient with a profuse roseola received six weekly injections of arsphenamin, $0.4 \mathrm{gm}$. each. Inunctions were then prescribed, but owing to severe gingivitis were discontinued after a few applications. Three weeks after the last arsphenamin treatment his spinal fluid was found to be normal, and the blood Wassermann reaction was negative. Thirty-four days after spinal puncture and without premonitory symptoms a left trochlear paralysis developed. Reexamination of the spinal fluid showed 31 cells, a globulin increase, complement fixation with 1 c.c. of fluid and a mastic 3 curve. The primary action of arsphenamin was suppression of the infection as evidenced by the negative serologic findings. The secondary action was the production of conditions previously described as rendering a neurorecurrence possible.

Appearance of or intensification of symptoms of neurosyphilis during a course of arsphenamin treatment cannot be considered a neurorecurrence if the foregoing conception of its genesis be accepted. Klauder ${ }^{12}$ includes such changes under neurorecurrences. He regards neurorecurrences, however, as belonging in the same category as Jarisch-Herxheimer reactions.

Treatment is probably not the only factor in the production of a neurorecurrence. Numerous patients with primary and secondary syphilis discontinue treatment after being rendered asymptomatic by one or several doses of arsphenamin. Many escape neurosyphilis; some return weeks or months later with asymptomatic neurosyphilis. It is the exceptional patient who develops a neurorecurrence. Obscure individual differences in reaction to syphilitic infection, strain variation in spirochetes or some as yet unknown factor may predispose to the development of intense meningeal lesions.

In two patients with tertiary syphilis, a process simulating a neurorecurrence developed four weeks after the cessation of arsphenamin treatment. It is striking that both presented a gummatous periostitis of the cranial bones. Moore ${ }^{13}$ has interpreted one as an extension of the syphilitic process from the inner diploe to the dura with a subsequent meningitis. Certainly these cases represent processes fundamentally different biologically from neurorecurrences developing after insufficient treatment of early secondary syphilis.

12. Klauder, J. V.: Early Neurosyphilis Asymptomatic with Report of Observations and Cases, Am. J. Syphilis 3:559, 1919.

13. Moore, J. E.: The Genesis of Neurosyphilis, Arch. Dermat. \& Syph. 4:55 (July) 1921. 
TABLE 2.-NEURORECURRENCES-

\begin{tabular}{|c|c|c|c|c|c|c|c|c|c|}
\hline & $\stackrel{8}{4}$ & 墒 & 这 & & 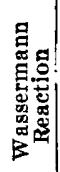 & Treatment & 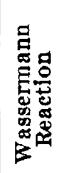 & Neurorecurrences & 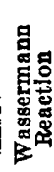 \\
\hline 1 & 17 & $\mathbf{F}$ & C & Primary...... & 0 & Arsphenamin, three times, & 0 & Acute syphilitic meningitis; & 0 \\
\hline 2 & 34 & $\mathbf{M}$ & C. & $\begin{array}{l}\text { Primary; annular papu- } \\
\text { lar }\end{array}$ & 4 & Arsphenamin, once, $0.4 \mathrm{gm}$. & $\cdots$ & 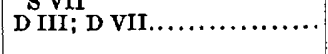 & $\mathbf{0}$ \\
\hline 3 & 60 & M & C & $\begin{array}{l}\text { Secondary, early; macu- } \\
\text { lopapular }\end{array}$ & 4 & $\begin{array}{l}\text { Arsphenamin, five times, } \\
2.0 \mathrm{gm} \text {. }\end{array}$ & 0 & S VII; D VII, VIII, C, V.... & 0 \\
\hline 4 & 35 & $\mathbf{M}$ & $\mathbf{w}$ & Secondary, early... & 4 & Arsphenamin, once, $0.4 \mathrm{gm}$. & $\ldots$ & S VIII, $\mathrm{C}, \mathrm{V}$. & 0 \\
\hline$\Sigma$ & 28 & $\mathbf{M}$ & $w$ & Primary, extragenital.... & 4 & Arsphenamin, six times, 1.8 & 4 & Acute syphilitic meningitis; & 0 \\
\hline 6 & 32 & $\mathbf{M}$ & $\mathbf{w}$ & $\begin{array}{l}\text { Secondary, early; roseo- } \\
\text { la; maculopapular }\end{array}$ & 0 & $\begin{array}{l}\text { Arsphenamin, six times, } 1.8 \\
\text { gm. }\end{array}$ & $\cdots$ & Acute syphilitic meningitis & 0 \\
\hline 7 & 21 & $\mathbf{F}$ & C & Secondary, early. & 4 & Arsphenamin, six times, 1.8 & 0 & $\begin{array}{l}\text { S vII, vIII, O; acute syph- } \\
\text { ilitic meningitis }\end{array}$ & 4 \\
\hline 8 & 21 & $\mathbf{M}$ & $\mathrm{C}$ & $\begin{array}{l}\text { Secondary, early; papu- } \\
\text { lar; pustular follicular }\end{array}$ & 4 & $\begin{array}{l}\text { Arsphenamin, six times, } 1.8 \\
\text { gm. }\end{array}$ & 2 & Posticus palsy... & 4 \\
\hline 9 & 26 & $\mathbf{M}$ & c & Secon & 4 & $\begin{array}{l}\text { Arsphenamin, six times, } 1.7 \\
\text { gm. }\end{array}$ & 4 & $\begin{array}{l}\text { D vII, VIII; S VIII; acute } \\
\text { syphilitic meningitis }\end{array}$ & 4 \\
\hline 10 & 22 & $\mathbf{M}$ & $\mathrm{C}$ & Primary..... & 4 & $\begin{array}{l}\text { Arsphenamin, two times, } \\
0.7 \mathrm{gm} \text {. }\end{array}$ & $\cdots$ & 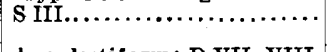 & 4 \\
\hline 11 & 20 & $\mathbf{M}$ & c! & Secondary, es & 4 & $\begin{array}{l}\text { Arsphenamin, seven times, } \\
2.7 \text { gm. }\end{array}$ & $\mathbf{0}$ & $\begin{array}{l}\text { Apoplectiform; D VII, VIII, } \\
\text { C; S VIII, C }\end{array}$ & 4 \\
\hline 12 & 39 & F & $\mathbf{W}$ & Secondary, early........... & 4 & $\begin{array}{l}\text { Arsphenamin, six times; } \\
\text { mercurial ointment, } 2 \text { mos. }\end{array}$ & 0 & o. S.; optic neuritis........... & 2 \\
\hline $\begin{array}{l}13 \\
14\end{array}$ & $\begin{array}{l}23 \\
22\end{array}$ & $\mathbf{M}$ & $\stackrel{\mathrm{C}}{\mathrm{W}}$ & $\begin{array}{l}\text { Primary.... } \\
\text { Primary.... }\end{array}$ & $\ldots$ & $\begin{array}{l}\text { Arsphenamin, once......... } \\
\text { Fifteen intramuscular in- } \\
\text { jections of mercury; ars- } \\
\text { phenamin, six times }\end{array}$ & $\cdots$ & 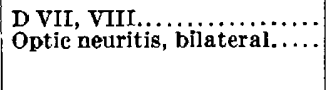 & $\ddot{0}$ \\
\hline 15 & 28 & $\mathbf{M}$ & $\mathbf{w}$ & Secondary, early; roesola & 4 & $\begin{array}{l}\text { phenam } \\
\text { Arsphen }\end{array}$ & $\cdots$ & $\begin{array}{l}\text { Acute iritis; acute syphilitic } \\
\text { menlngitis }\end{array}$ & $\cdots$ \\
\hline 16 & 52 & $\mathbf{M}$ & $\mathbf{w}$ & $\begin{array}{l}\text { Secondary, early; papu- } \\
\text { lar }\end{array}$ & 4 & Arsphenamin, five times... & 0 & s viI, VIII, 0, v.............. & 0 \\
\hline 17 & 39 & $\mathbf{M}$ & $\mathrm{C}$ & Secondary, early; roseola & 4 & $\begin{array}{l}\text { Arsphenamin, five times, } \\
2.0 \mathrm{gm} \text {. } \\
\text { Arsphenamin, six times, } 2.3\end{array}$ & $\begin{array}{l}0 \\
0\end{array}$ & $\begin{array}{l}\text { D VII; acute iritis........... } \\
\text { Headache; S VIII, v, c..... }\end{array}$ & $\begin{array}{l}0 \\
0\end{array}$ \\
\hline 18 & 24 & $\mathbf{M}$ & C & Secondary, early; roesola & 4 & $\begin{array}{l}\text { gm. } \\
\text { Arsphenamin, ? times......... }\end{array}$ & $\cdots$ & Acute syphilitic meningitis.. & $\mathbf{0}$ \\
\hline 19 & 35 & $\mathbf{M}$ & $\mathbf{w}$ & $\begin{array}{l}\text { Secondary, early; macu- } \\
\text { lopapular }\end{array}$ & $\cdots$ & $\begin{array}{l}\text { Arsphenamin, six times, } 2.4 \\
\text { gm. }\end{array}$ & 0 & VIII, $\mathrm{C}$ and $\mathrm{v}$, bilateral..... & 0 \\
\hline $\begin{array}{l}20 \\
21\end{array}$ & 28 & $\begin{array}{l}\mathbf{M} \\
\mathbf{M}\end{array}$ & $\stackrel{\mathrm{C}}{\mathrm{W}}$ & $\begin{array}{l}\text { Secondary, early............. } \\
\text { Secondary, early......... }\end{array}$ & $\begin{array}{c}4 \\
\cdots\end{array}$ & Arsphenamin, twice. & $\cdots$ & acute & 4 \\
\hline 22 & 28 & $F$ & c & $\begin{array}{l}\text { Secondary, early; papu- } \\
\text { lar; facial paralysis }\end{array}$ & 4 & $\begin{array}{l}\text { Arsphenamin, four times, } \\
1.4 \mathrm{gm} \text {. }\end{array}$ & $\mathbf{0}$ & Acute syphilitic meningitis; & 0 \\
\hline 24 & 30 & $\mathbf{M}$ & $\mathbf{W}$ & Secondary, $e$ & $\cdots$ & $\begin{array}{c}\text { Nine intramuscular injec- } \\
\text { tions mercury; arsphena- } \\
\text { min, ten times } \\
\text { Neo-arsphenamin, twice..... }\end{array}$ & $\cdots$ & Headache..................... & 0 \\
\hline 25 & 27 & $\mathbf{M}$ & $\mathrm{O}$ & Secondary, early; papular & 4 & enamin, six times, 2.4 & 0 & p viIr, $\mathrm{c} ; \mathrm{s}$ VIII, $\mathrm{c}, \mathrm{v} . . .$. & 0 \\
\hline 26 & 19 & $\mathbf{M}$ & $\mathrm{W}$ & Secondary, early & 4 & $\begin{array}{l}\text { Amsphenamin, six times, } 2.4 \\
\text { gm. }\end{array}$ & 0 & D I & 0 \\
\hline 27 & 23 & $\mathbf{M}$ & $\mathrm{C}$ & $\begin{array}{l}\text { Secondary, early; pustu- } \\
\text { lar }\end{array}$ & 4 & Arsphenamin, two times, 0.8 & 0 & Epilept form attacks......... & 0 \\
\hline 28 & 32 & $\mathbf{M}$ & $\mathbf{W}$ & Secondary, early... & 4 & Arsphenamin, twice.......... & $\cdots$ & D VII, VIII, C, V; s VIII, & 0 \\
\hline 29 & 23 & $\mathbf{M}$ & $\mathrm{C}$ & Secondary, early......... & 4 & $\begin{array}{l}\text { Arsphenamin, six times, } 2.4 \\
\text { gm. }\end{array}$ & 0 & Headache; S VII, VIII, C, V & 0 \\
\hline 30 & 26 & $\mathbf{M}$ & $\mathbf{W}$ & Primary............. & 4 & Neo-arsphenamin, twice..... & $\cdots$ & Acute syphilitic meningitis.. & 4 \\
\hline 31 & 54 & $\mathbf{F}$ & $\mathbf{w}$ & Secondary, early........... & 4 & $\begin{array}{l}\text { Neo-arsphenamin, six times, } \\
4.8 \mathrm{gm} .\end{array}$ & $\ldots$ & $\underset{\text { syphilitic meningitis }}{\text { Coma; s V, VII; acute }}$ & 4 \\
\hline 32 & 38 & M & $w$ & Secondary, early; papular & $\cdots$ & Arsphenamin, three times... & $\cdots$ & $\begin{array}{l}\text { Acute syphilitic meningitis; } \\
\text { S III, V }\end{array}$ & 4 \\
\hline 33 & 22 & $\mathbf{M}$ & $\mathbf{w}$ & Secondary, early; papular & 4 & Neo-arsphenamin, six times & 4 & $\begin{array}{l}\text { Hemiplegia; acute syphil- } \\
\text { itic meningltis }\end{array}$ & 4 \\
\hline 35 & 26 & $\mathbf{M}$ & $\mathbf{w}$ & Secondary, early.. & $\cdots$ & $\begin{array}{l}\text { Arsphenanifn, three times, } \\
1.2 \text { gm.; neo-arsphenamin, } \\
\text { four times, } 2.4 \text { gm. } \\
\text { Arsphenamin, five times.... }\end{array}$ & $\cdots$ & $\begin{array}{l}\text { Acute syphilitic meningitis.. } \\
\text { Acute syphilitic meningitis.. }\end{array}$ & 1 \\
\hline $\begin{array}{l}36 \\
37\end{array}$ & $\begin{array}{l}52 \\
28\end{array}$ & $\frac{\mathbf{M}}{\mathbf{M}}$ & $\underset{W}{W}$ & $\begin{array}{l}\text { Secondary, early } . . . . . . . . . \\
\text { Secondary, early............ }\end{array}$ & $\begin{array}{l}4 \\
4\end{array}$ & $\begin{array}{l}\text { Neo-arsphenamin, twice..... } \\
\text { Arsphenamin, six times..... }\end{array}$ & $\cdots$ & $\begin{array}{l}\text { Aeute syphilitic } \\
\text { Optic neuritis.. }\end{array}$ & $\begin{array}{l}0 \\
0\end{array}$ \\
\hline 38 & 21 & $\mathbf{F}$ & $\mathrm{C}$ & $\begin{array}{l}\text { Secondary, early; pustu- } \\
\text { lar }\end{array}$ & 4 & $\begin{array}{l}\text { Mercurial ointment, } 2 \text { mos.; } \\
\text { arsphenamin, twelve times, } \\
2.9 \mathrm{gm} .\end{array}$ & 0 & D VII, VIII, C, V & 0 \\
\hline 39 & 22 & $\mathbf{F}$ & $\mathbf{w}$ & Secondary, early... & 4 & $\begin{array}{l}\text { Arsphenamin, twice; silver } \\
\text { arsphenamin, four times }\end{array}$ & 0 & Acute syphilitic meningltis.. & 0 \\
\hline
\end{tabular}

* The degree of fixation in the Wassermann test is given numerical value: $4=100$ per cent.; $3=75$ per cent.; $2=50$ per cent.; $1=25$ per cent.; $0=$ no flxation. The involved cranial nerves are designated by Roman numerals; $\mathrm{D}=$ right; $\mathrm{S}=$ left; $\mathrm{C}=$ cochlear; $\mathrm{V}=$ vestibular. 


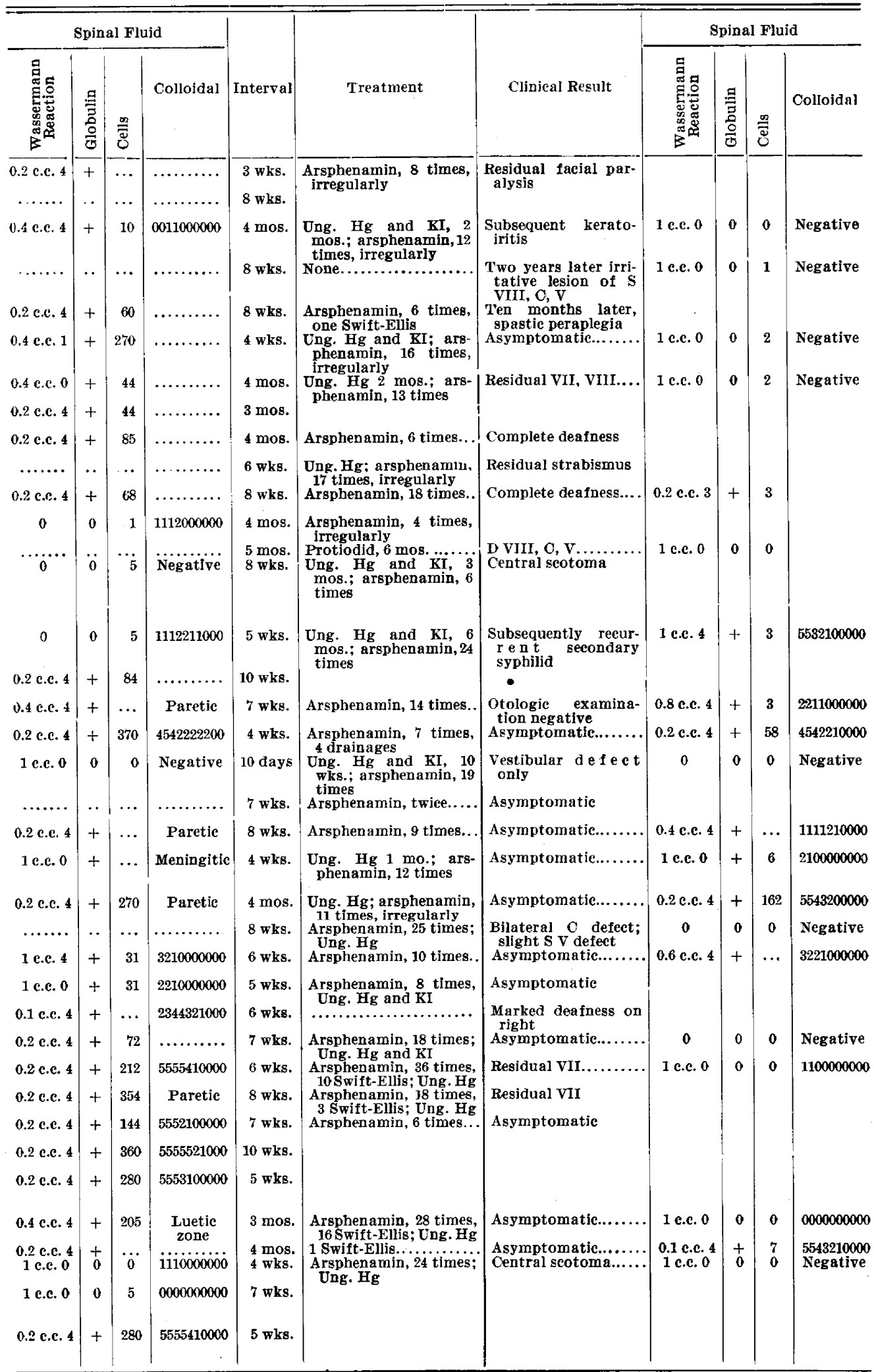




\section{PATHOLOGY OF NELRORECURRENCES}

Since therapy is so successful in controlling these complications few patients have come to necropsy. Pirilä ${ }^{14}$ made a detailed pathologic study of two neurorecurrences developing after combined mercury and arsphenamin treatment. He found a cellular, chiefly lymphocytic, infiltration of the vessel walls and a subendothelial proliferation, not only of the larger vessels at the base of the brain and their branches, but also of the smaller vessels of the meninges. In places the intimal changes were of sufficient degree to obliterate the vessels entirely. These vascular lesions were combined with an intense leptomeningitis, especially marked in the region of the chiasm and pons and extending over the cortex and cerebellum. Such pathologic changes explain satisfactorily the cases in Group 1 which clinically show signs of an acute meningitis with focal lesions chiefly in the nature of a cranial nerve involvement, less often with a cortical or vascular localization. It is probable that Group II also depends on a similar but less intense meningitic process.

However, all neurorecurrences cannot be explained on such a pathologic basis. Lloyd's ${ }^{15}$ patient, who died of appendicitis during the acute stage of the neurorecurrence, exemplifies another type of process, not a diffuse meningovascular neurosyphilis, but a focalized lesion. The patient was originally treated for primary syphilis with five doses of arsphenamin. Six months after the primary lesion, he developed a staggering gait with a tendency to fall to the left, deafness in both ears, which became complete on the right, tinnitus, a low grade bilateral optic neuritis and a left facial paresis. Otologic examination showed that the right labyrinth was completely, and the left partially, involved. The blood Wassermann test was negative, the spinal fluid had a positive Wassermann reaction and a pleocytosis of 910 . The cerebellum, cerebrum, pons and meninges were normal. In the medulla there was a lymphocytic infiltration of Deiters' nucleus on the right side. The axis cylinders of both auditory nerves were swollen and tortuous. Within the nerves was a perivascular infiltration of lymphocytes and plasma cells, and the sheaths of the nerves were similarly infiltrated. No mention was made of a microscopic study of the optic or facial nerves. Striking are the focal character of the cerebral changes and the absence of diffuse changes as in Pirilä's cases. This report is very instructive in that it demonstrates that a high pleocytosis does not necessarily imply an intense and diffuse meningeal reaction, but may result from one or several focal lesions.

14. Pirilä, P.: Ueber die frühluetische Erkrankung des Zentralnervensystems, Arb. a. d. Path. Institut der Univ. Helsingfors 11:91, 1919.

15. Lloyd, J. H. : Syphilis of the Eighth Nerve, Arch. Neurol. \& Psychiat. 5: 572 (May) 1921. 
In Patients $12,14,16,20,37$ and 38 in this series there were no clinical signs of meningeal irritation, and the spinal fluid was normal. The only evidence of neurosyphilis was a facial paralysis, an auditory defect or an optic neuritis. In such cases it is reasonable to suppose that as in Lloyd's case there were no diffuse meningovascular changes, but the lesions were focal, either nuclear or of the nature of a peripheral neuritis.

Neurorecurrences may then be divided pathologically into two groups: (1) a diffuse meningovascular process (Pirilä's cases), and (2) focal lesions involving especially the second, seventh and eighth cranial nerves without diffuse cerebral changes (Lloyd's case).

PROGNOSIS OF NEURORECURRENCES

The prognosis of the neurorecurrences entails two distinct considerations: first, the immediate relief from meningitic symptoms and the restoration of function of important sensory structures, especially the optic and auditory nerves; and second, the ultimate outcome of the neurosyphilis.

If intensive antisyphilitic treatment is instituted early, meningitic symptoms subside rapidly. One patient, who had been in coma fortyeight hours, recovered entirely with the exception of a residual facial paresis under spinal drainage associated with the intravenous administration of neo-arsphenamin and mercurial inunctions. Optic neuritis clears up with slight permanent defects. In two cases a central scotoma persisted. Of the canial nerves, the greatest concern is caused by the auditory. If cochlear symptoms are moderate, restoration may be so nearly complete that careful otologic examination is necessary to detect residual defects. On the other hand, when such symptoms are marked, one may predict serious and permanent functional impairment. In the patient who became deaf over night, complete deafness persisted. Pronounced vestibular symptoms do not aggravate the prognosis as when irritative disturbances disappear, the remaining defect causes no subjective symptoms. Alexander, ${ }^{16}$ who has made an exhaustive study of the auditory nerve in neurorecurrences, classifies involvement of this nerve into four groups according to symptoms and prognosis: 1. Symptoms moderate; slight diminution in hearing, tinnitus, and spontaneous nystagmus, without vertigo; prognosis favorable, often complete functional restoration.

2. Marked cochlear symptoms, either isolated or combined with a vestibular lesion; prognosis less favorable, complete restoration rare; commonly a residual defect and occasionally progressive increase in deafness.

16. Alexander, G.: Die Syphilis des Gehörorganes, Alfred Holder, 1915, p. 25. 
3. Isolated vestibular lesion; prognosis favorable. In 30 per cent. of the cases in which vestibular involvement begins with intense vertigo, there is a permanent loss of function of the static labyrinth.

4. Apoplectiform onset of symptoms; severe vertigo and marked deafness; prognosis bad; at times complete deafness results.

The ultimate outcome of neurosyphilis cannot be predicted because the period of observation has been too short. As is true with the meningovascular type of neurosyphilis in general, routine antisyphilitic treatment consisting of arsphenamin and mercury by inunctions at times accomplishes all that can be desired. In Patients 3, 6, 7 and 29 in this series such treatment produced a clinical and serologic cure. Patients 30 and 35 have been submitted to intraspinal therapy, and the results have been satisfactory.

The group of neurorecurrences which result from focal lesions without diffuse meningovascular changes should offer an especially favorable prognosis if intensive antisyphilitic treatment is instituted at once. Patients 20 and 37 in this series with normal spinal fluids shortly after the onset of the neurorecurrence and clinically free from meningitic symptoms showed no spinal fluid abnormalities after a year of thorough treatment. On the other hand, in Patient 16 treatment was neglected until the subsequent development of a recurrent secondary syphilid on the scrotum. Reexamination of the spinal fluid now showed a globulin increase, complement fixation and a paretic gold curve. The primary focus in the facial and auditory nerves probably served to disseminate the infection.

Gennerich ${ }^{17}$ urges intraspinal treatment in all neurorecurrences. He states that results by such therapy are more rapid and more permanent, also there is a better prospect of restoring the function of the cranial nerves affected. When neurorecurrences develop six or more weeks after arsphenamin was administered in sufficient dosage, intensive intravenous therapy may suffice. However, when neurosyphilis develops during a course of arsphenamin, ten to fourteen days after the completion of a course or after several thorough courses, satisfactory results can be obtained only by the intraspinal method.

\section{PROPHYLAXIS}

Exponents of simultaneous arsphenamin and mercurial therapy claim that such a procedure reduces the incidence of neurorecurrences. Only two patients who received initial treatment in this clinic had used inunctions to a considerable extent, and in one of these the dosage of arsphenamin had been unusually small. Such statistics demonstrate without question the protective action of mercury against neurorecur-

17. Gennerich: Die Syphilis des Zentralnervensystems, p. 147. 
rences. It should, however, be noted that no patient in this clinic, who had persisted in the course of mercury immediately following arsphenamin according to routine procedure, had developed precocious clinical neurosyphilis. It is difficult to grasp how any ambulatory clinic can eliminate neurorecurrences entirely, as interruption of treatment by the patient cannot be prevented in many cases even with the cooperation of a well organized social service. The incidence of neurorecurrences can be materially reduced by special supervision of patients with primary and early secondary syphilis until a thorough course of mercury has been administered. A survey of this series indicates that it is immaterial whether the mercury be employed simultaneously with arsphenamin or immediately following a course of the latter.

SUMMARY

A series of thirty-nine neurorecurrences are tabulated. Their symptomatology, genesis and prognosis are discussed. Pathologically there are two types, a diffuse meningovascular process and a process limited to one or more focalized lesions. In the former the spinal fluid is always abnormal, in the latter it may show marked abnormalities or may be entirely normal.

Prophylaxis of such lesions depends on a thorough mercurial treatment. It seems immaterial whether mercury is administered during or immediately following a course of arsphenamin. 